\title{
Micro-XRF Investigation of Decoration Materials and Painting Techniques in Three 18th-19th Century Mosques in Berat, Albania
}

\author{
Eglantina Merkaj, ${ }^{1,2}$, Nikolla Civici² \\ ${ }^{1}$ Department of Physics, Faculty of Natural Sciences, University of Tirana, Tirana, Albania \\ ${ }^{2}$ Institute of Applied Nuclear Physics, University of Tirana, Tirana, Albania \\ Email: eglantinamerkaj@yahoo.com
}

How to cite this paper: Merkaj, E. and Civici, N. (2019) Micro-XRF Investigation of Decoration Materials and Painting Techniques in Three 18th-19th Century Mosques in Berat, Albania. Journal of Materials Science and Chemical Engineering, 7, 1-15.

https://doi.org/10.4236/msce.2019.75001

Received: March 27, 2019

Accepted: May 11, 2019

Published: May 14, 2019

Copyright $\odot 2019$ by author(s) and Scientific Research Publishing Inc. This work is licensed under the Creative Commons Attribution International License (CC BY 4.0).

http://creativecommons.org/licenses/by/4.0/

(c) (i) Open Access

\begin{abstract}
We will present here the data obtained from the examination with micro-XRF of a series of micro samples taken from the decorations of three mosques in Berat, Albania. These are parts of an Islamic religious complex situated at the central area of the old town and include the "Helvetia Tekke", the King's Mosque and the Bachelors' Mosque, which were built or reconstructed during the second half of the $18^{\text {th }}$ century and the beginning of the $19^{\text {th }}$ century. Beside the architectural values of the buildings, the interiors of the monuments are decorated with paintings of the walls and the ceilings made of carved wood. The results of the measurements indicate that the preparation layer of the paintings on wooden ceilings was made of gypsum while that of the wall paintings was made of calcium carbonate. The palette includes the following inorganic pigments: lead white, gold, yellow and red ochre, vermilion, red lead, a copper based green, smalt and probably carbon black at Helvetia Tekke; green earth, yellow ochre, red ochre, red lead and cinnabar at Bachelors' Mosque and red lead, orpiment and Indigo should have used for the original decorations of the ceilings in King Mosque, which are later overpainted with traditional pigments like yellow and red ochre, prussian blue and other modern pigments. Organic pigments, probably indigo and carbon black should have been used for the blue and black color. Similarities and differences observed between the monuments and indications about the painting technique as well as the degradation of some pigments will also be discussed.
\end{abstract}

\section{Keywords}

Micro-XRF, Inorganic Pigments, Islamic Art, Berat, Albania 


\section{Introduction}

The town of Berati, designated a UNESCO World Heritage Site in 2008, is situated in central Albania and represents a centre that has been continuously inhabited from its foundation ( $4^{\text {th }}$ century BC) up to present. Ottoman, Byzantine and Roman reconstructions are clearly superposed on the Illyrian foundations of the castle walls. Several old churches dating from 13th-19th century, mosques (15-19 cent) decorated with wall paintings together with characteristic architecture houses are preserved in the old part of the town. The designation of Berati as a "Museum town" in 1961 by the Albanian government helped for the preservation of the different monuments [1] [2].

The investigated mosques are situated at the central part of the old town in Berat. The Islamic religious complex which included King Mosque, "Helvetia Tekke" and the dervishes' dwelling rooms was built during the $15^{\text {th }}$ century. The present buildings of Tekke and the mosque were reconstructed almost completely during the end of $18^{\text {th }}$ century and the beginning of the $19^{\text {th }}$ century. The Bachelor's Mosque, situated not far from this complex, was built during the same period [1] [2].

"Helvetia Tekke" has been rebuilt by Ahmet Kurt Pasha, the ruler of the time, in 1782 over the foundations of the older $15^{\text {th }}$ century building. It is composed by the prayer hall with a square plan, a small ambience for special religious services and by a gracious portico which preceded the entrance to the prayer hall, whose columns were taken from the antique city of Apollonia. The inner walls of the prayer hall have been decorated with frescoes and the wooden ceiling is decorated with paintings valued as the most beautiful of the time (Figure 1). The inner decorations have been carried out by Master Dush Barka [1].

The King Mosque, also known as the Sultan's Mosque or Sultan Bayezid Mosque, was built in the $15^{\text {th }}$ century by the Ottoman Sultan Bayezid II for the local Albanian population. As written on an inscription, the building of the mosque was reconstructed during 1832-1833. It consists of the main prayer hall, the minaret and a large portico. It is thought that the portico, which has been used as additional prayer hall, was extended during the reconstruction works of 1832-1833. The lower part of the minaret belongs to the $15^{\text {th }}$ century construction while the upper part is reconstructed later [1] [2]. At present, the inner walls of the prayer hall are not decorated while the wooden ceilings are decorated with geometric and floral motifs (Figure 2).

The Bachelors' Mosque is a cultural and religious monument, located in the south of Berat's Mangalem neighborhood. The mosque was built in the early $19^{\text {th }}$ century, most probably 1824-1825, to serve the needs of the bachelors of the various guilds. It was built on two floors to accommodate the steep terrain. The minaret of the mosque is low. The praying hall, situated on the second floor, is preceded by the portico with arcades on three sides of it. Beautiful wall paintings decorate the internal walls of the praying hall on two horizontal rows as well as the upper part of the outside walls of the whole mosque (Figure 3). According to an inscription, the mosque was decorated during 1827-1828 [1] [2]. 


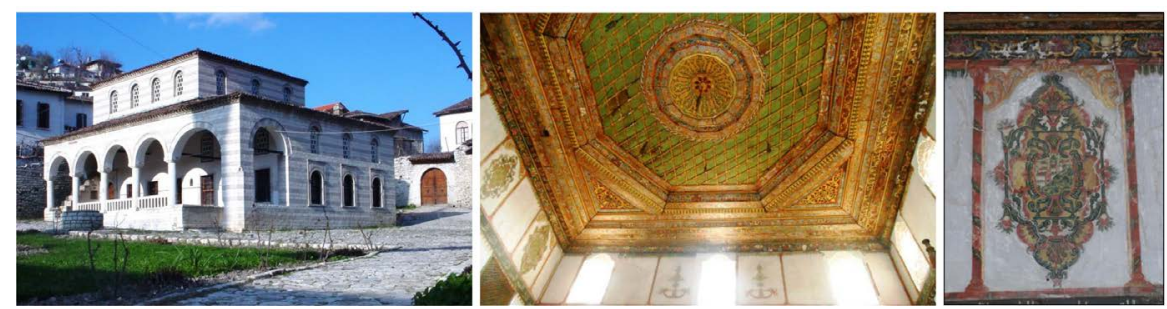

Figure 1. Photo of the Helvetia Tekke, the decorated ceiling and decorations on the side walls.
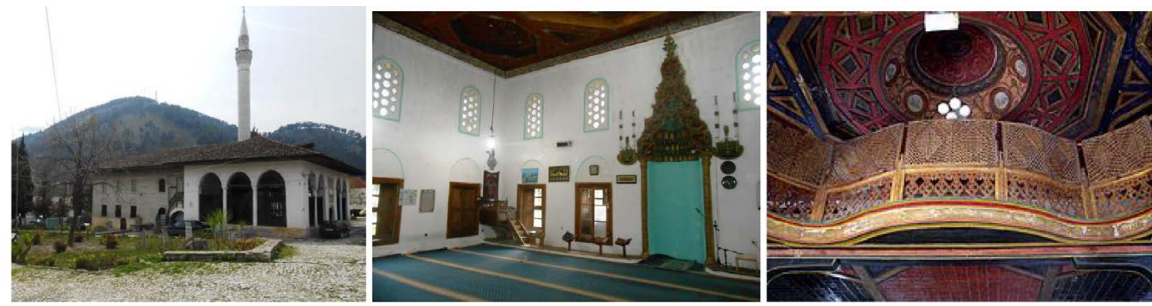

Figure 2. Photo of the King Mosque, the praying hall and the decorated ceilings.
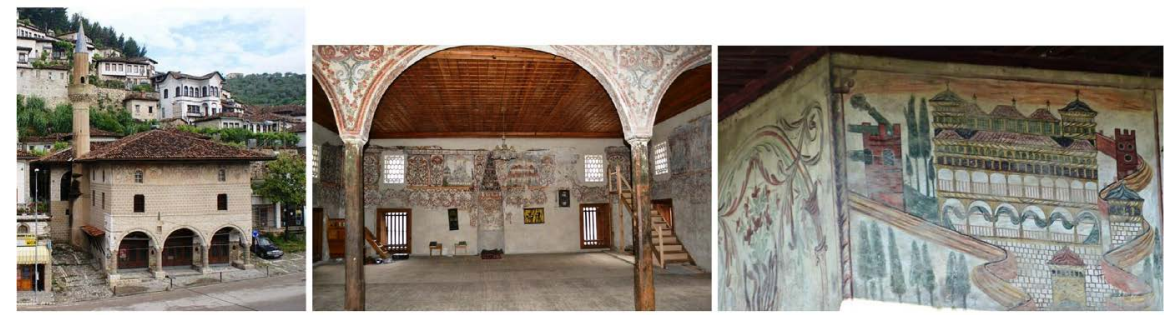

Figure 3. Photo of the Bachelor's Mosque, decoration of the praying hall and those on the outside walls.

Partial restoration works either of the buildings or the decorated areas of the studied mosques were carried out during the period 1970-1990 [3] [4] [5]. Recently the responsible authorities are planning a big restoration project and a sampling campaign was organized, during which a series of samples of construction and decorative materials were collected in different parts of the buildings of the mosques.

The study of the materials and techniques employed for the decoration of the buildings, complementing the information from historical and aesthetic data, contributes to the integrated knowledge of the building and artist as well as provide useful information for their restoration [6]. The present study aimed at the identification of the main types of painting materials (pigments and ground) that will enable the selection and use of similar and/or compatible materials during the restoration process. On the other side the results allow us to compare the painting technique and materials used for the decoration of the three mosques which belong to approximately the same period. To our knowledge this study is the first attempt for the systematic study of decoration materials' used for the Muslim religious buildings in Albania.

During the last years a series of modern analytical techniques have been de- 
veloped and used for the investigation of the decorative materials either in-situ or in laboratory conditions, when sampling is permitted [7]. In this study micro-XRF is used for the analysis of the samples from the decorated areas. The application of XRF techniques to pigment identification is based on the identification from the spectrum of one or more "key elements", which are the main constituents of the pigment. In most of the cases the combination of color and "key elements" lead to effective inorganic pigment identification. A limitation of the technique, related to the insufficient sensitivity of XRF for low $\mathrm{Z}$ elements, is the inability to identify organic pigments [8] [9].

\section{Experimental}

The samples from the decorated parts of the three mosques were collected by the restorers mostly at areas belonging to the original painting. The samples were collected by removing small pieces, a few $\mathrm{mm}$, of pigment and ground from near to areas already damaged and placed in clean plastic bags. Special attention was paid to avoid further damage.

In "Helvetia Tekke" we collected 28 samples that include the main colors of the wall paintings ( 9 samples), painting of the ceiling (12 samples) and paintings of the other wooden parts of the hall (7 samples). In the King mosque we collected 9 samples most of them from the painted wooden ceiling (6 samples) and 16 samples were collected in the Bachelor's mosque mostly from the paintings on the internal and external walls (14 samples).

The samples were analyzed by the Micro-XRF spectrometer ARTAX 800 (Bruker Gmbh). The spectrometer is composed of low power (30 W; max HV $50 \mathrm{kV}$ ), micro focus, air cooled, $\mathrm{Rh}$ anode $\mathrm{X}$-ray tube to which a condensing capillary lens is attached, allowing to focus the excitation radiation into a spot of about $75 \mu \mathrm{m}$ diameter and Peltier cooled SDD detector (area-10 $\mathrm{mm}^{2}$; FWHM $\sim 155 \mathrm{eV}$ at $5.9 \mathrm{keV}$ ). The measuring head is equipped with CCD camera for sample positioning and can be moved in XYZ directions by PC controlled step motors. The spectrometer allows single point measurements as well as programmed line and mapping scans with a spatial resolution in the sub-mm range. In each pixel a spectrum was collected for a short time and the net characteristic $\mathrm{X}$-ray peak areas were calculated using the spectrum fitting software. The resulting peak areas were further converted to two or three-dimensional matrix (X-pixels, Y-pixels, I-elements) and plotted in intensity readouts graphs.

In Table 1 are presented the measuring conditions, which allow the identification of all elements with atomic number higher than 14 through their characteristic $\mathrm{K}$ or $\mathrm{L}$ lines.

For the identification of the painting materials several single point measurements were performed on both the painted part and the ground layer part of the samples. The cross section of some samples were investigated in "Line scan" mode, during which short sequential measurements were performed through a line on the sample's cross section using a spot distance of $0.03 \mathrm{~mm}$. Plotting the intensities of characteristic X-ray lines of the different elements versus the 
Tabel 1. Measuring conditions.

\begin{tabular}{cccc}
\hline High voltage/kV: & 45 & Anode: & Rh \\
\hline Current/ $\mu \mathrm{A}:$ & 202 & Filter: & No filter \\
Atmosphere: & Air & Optic: & Lens $0.060 \mathrm{~mm}$ \\
Time/s: & 100 & Energy range/keV: & 50.0 \\
\hline
\end{tabular}

position enables the identification of the different preparatory and painted layers used by the artist. During these measurements the cross section of the sample was positioned perpendicular to the X-ray beam and a rather flat area was selected for the scan.

\section{Results and Discussion}

The identification of pigment types was made by comparing the spectra measured on both sides of the sample, the painted side and the ground side. In Figures 4-14 are presented the XRF spectra of some samples that cover most of the colours and identified pigments in all the monuments. In each figure the spectrum of the pigment layer is overlapped with the spectrum of the corresponding ground layer so that the characteristic elements related with the pigment are clearly evidenced.

The results obtained by the measurement of the samples collected at each monument are summarized in Tables 2-4. In these tables along with the sample number and color are specified the type of support material and the main elements detected in the respective spectra of both sides of the samples and the corresponding type of suggested ground material and pigment. In parenthesis are also shown the elements present in the respective spectra with low intensity, which can indicate the presence of small amounts of additional pigments.

In the spectra taken from the ground side of the different samples we observed the significant presence of some elements like $\mathrm{Pb}$ or As, which suggested that the ground layer or sample could be more complex than expected. This led us to the study of the cross sections of some samples by micro-XRF aiming the identification of the possible different layers in the sample. This is of great importance for the correct interpretation of the pigment spectra and their identification, because most of the elements from different layers can be present in the spectrum. It also gives information about the technique used by the artist.

The line scan measurements performed on the cross section of wall painting samples from Helvetia Tekke and Bachelor's mosque are presented in Figure 15, where the intensities of characteristic X-ray lines of the main elements identified in the spectra at each position of the beam are plotted versus the position. The measurements started from the ground layer towards the painted layers. In both plots we observed a stable intensity of Calcium, indicating the presence of a layer made of Calcite, and then at the border we have the peaks of the elements related with the pigments of the respective red colors. The presence of $\mathrm{Fe}$ and $\mathrm{Pb}$ in the red color of the sample from Helvetia Tekke indicates the use of pigments Red 


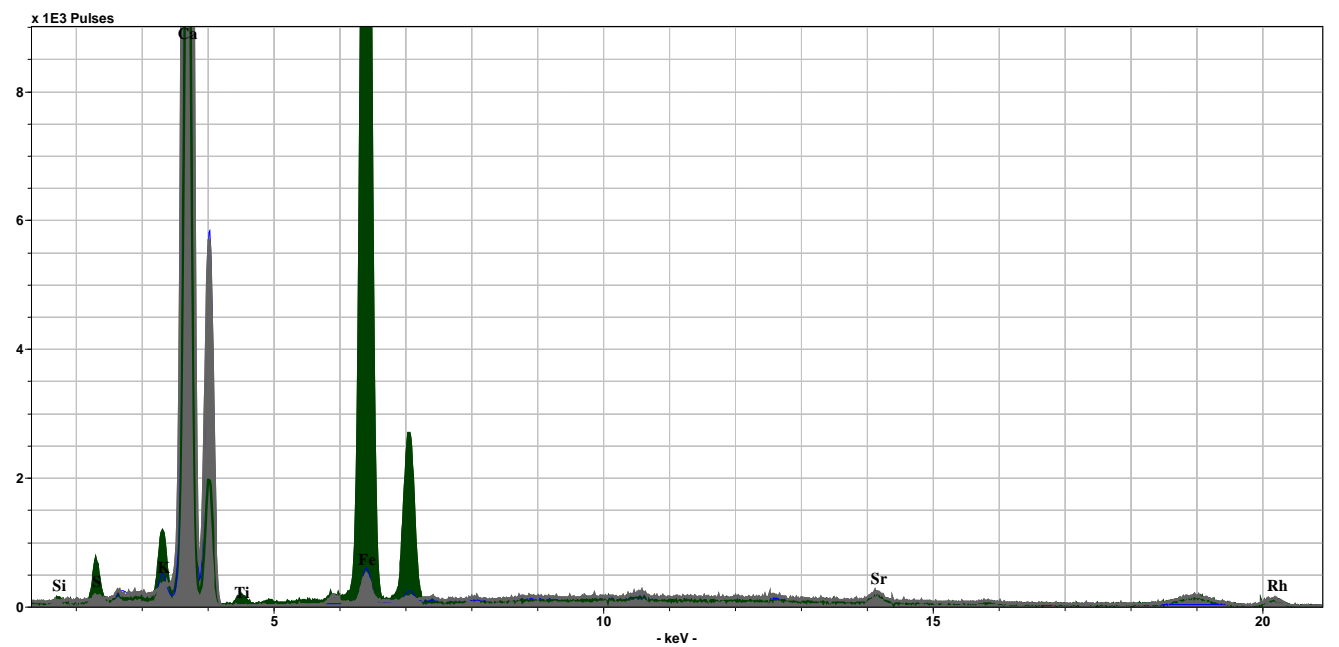

Figure 4. XRF spectra of the ground layer (gray) and the green color (green), sample BM23 (green earth).

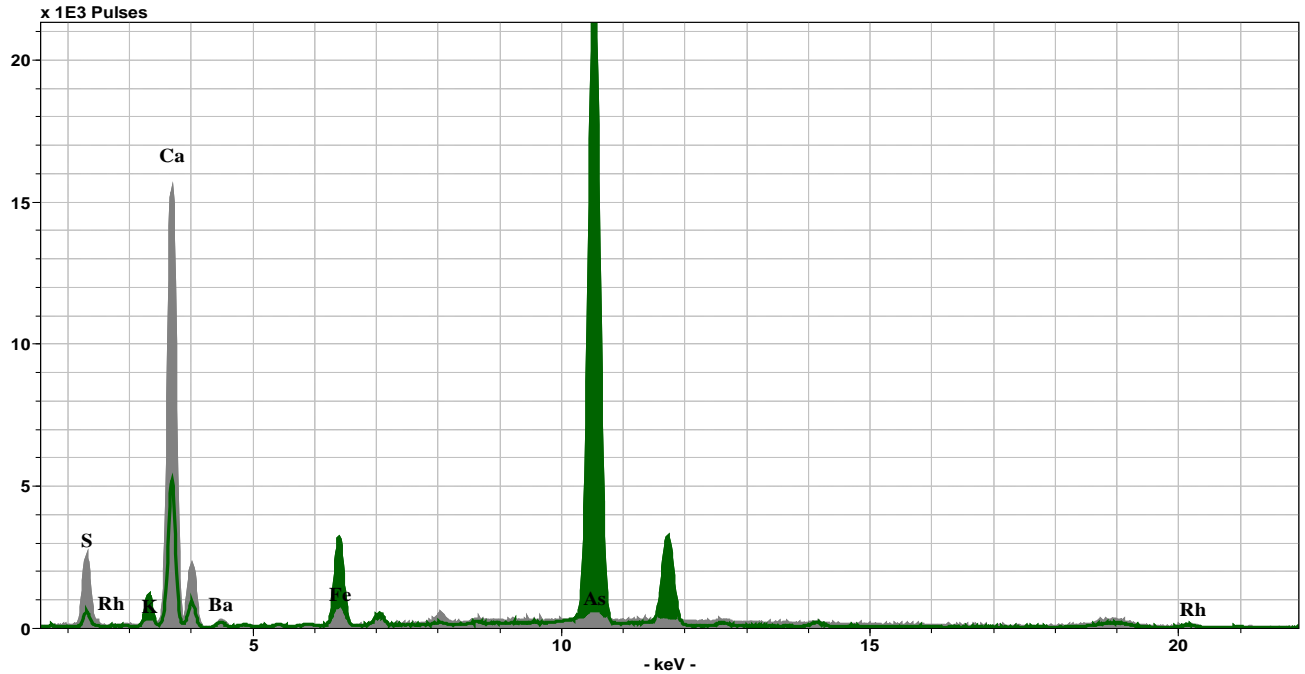

Figure 5. XRF spectra of the ground layer (gray) and the green color (green), sample KM44 (Orpiment + Indigo).

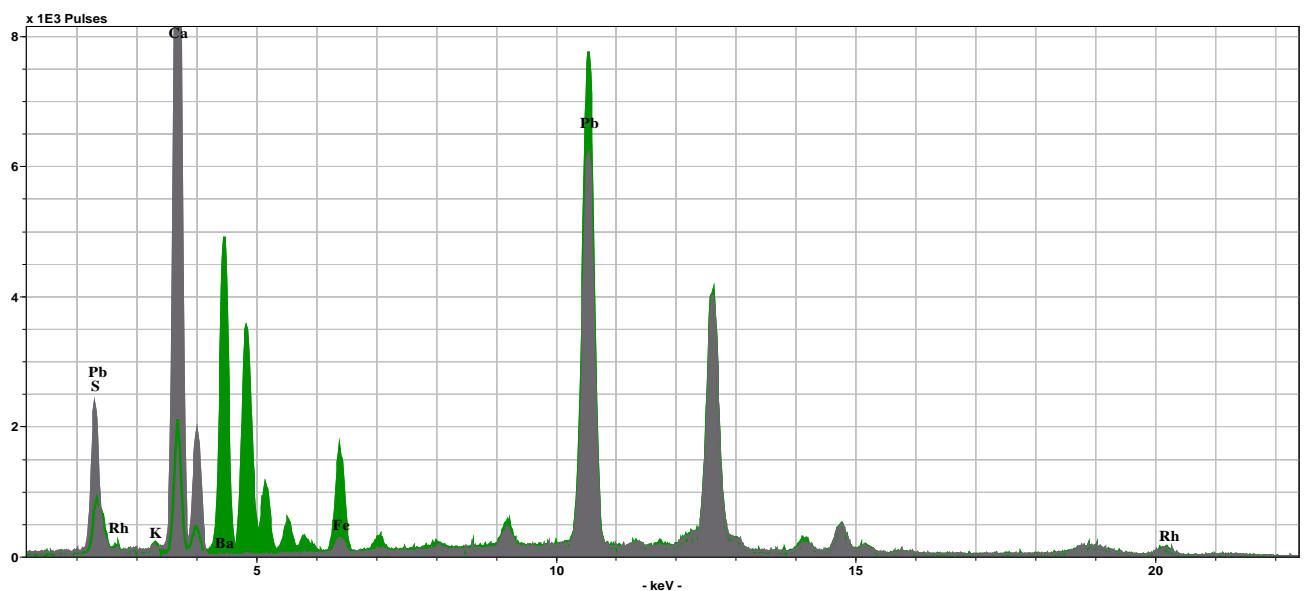

Figure 6. XRF spectra of the ground layer (gray) and the green color (green), sample KM38 (modern green). 


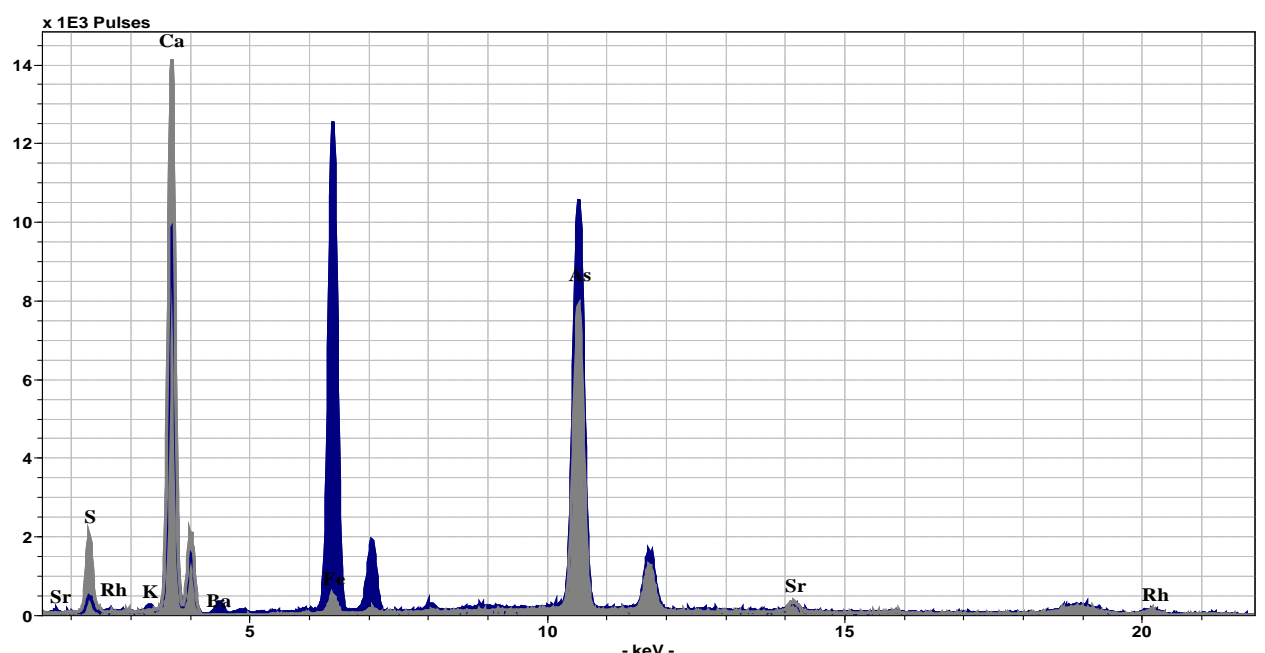

Figure 7. XRF spectra of the ground layer (gray) and the blue color (blue), sample KM39 (Prussian blue).

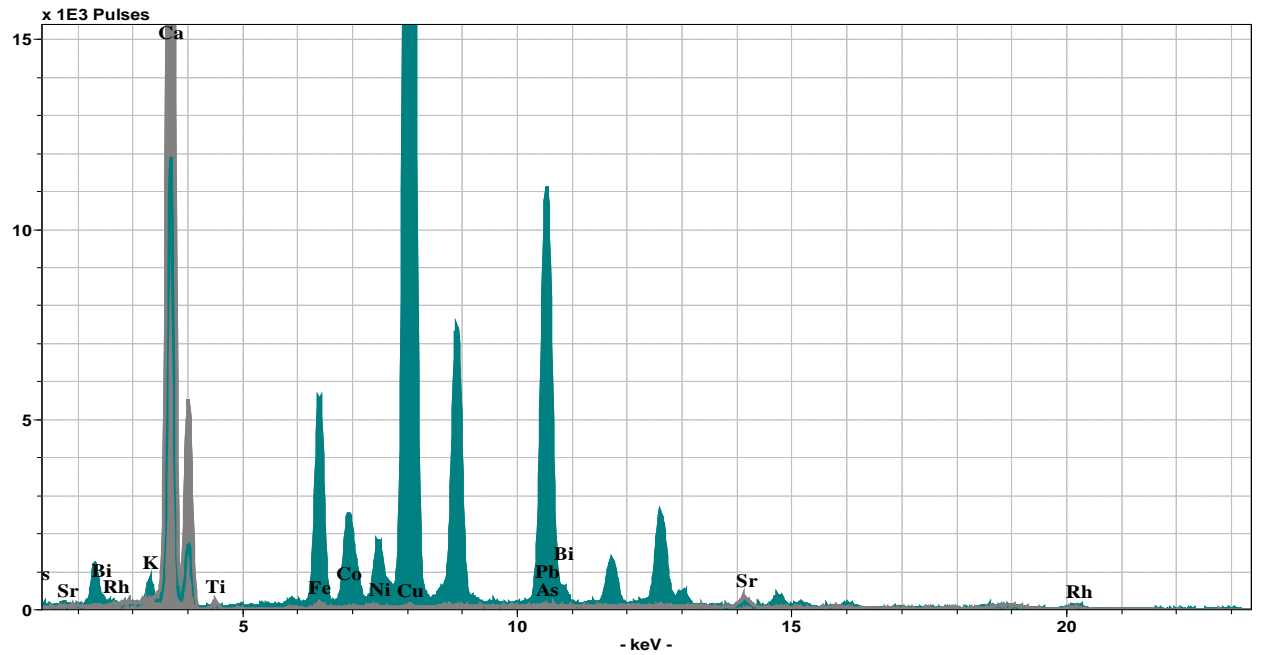

Figure 8. XRF spectra of the ground layer (gray) and the green bluish color (green bluish), sample HT35 (Cu-based + smalt).

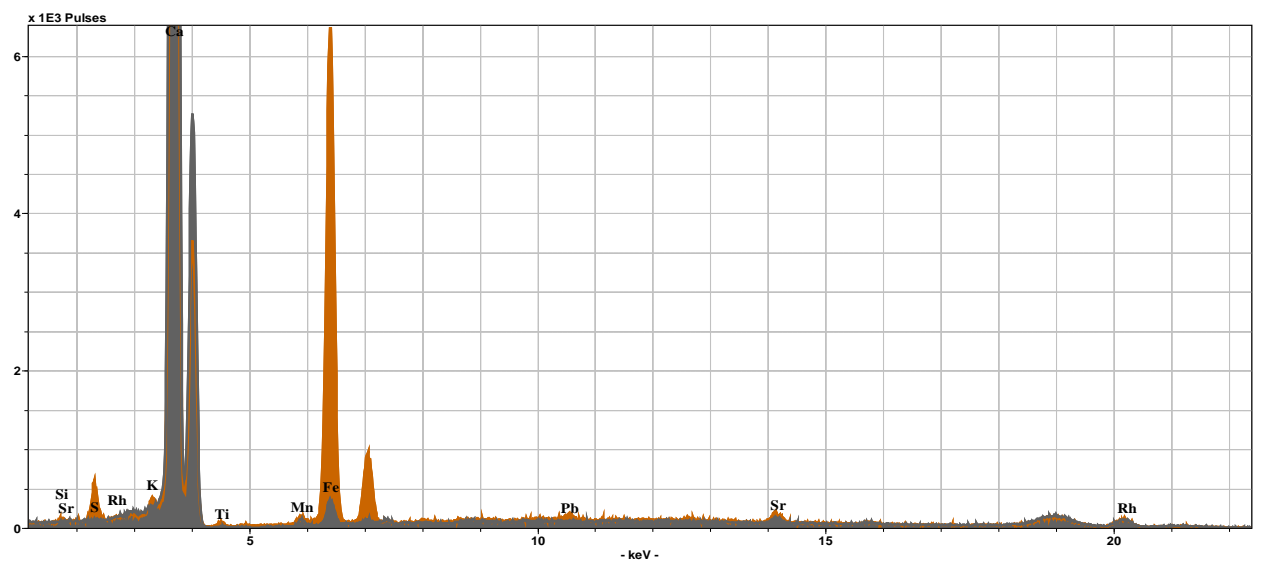

Figure 9. XRF spectra of the ground layer (gray) and the yellow color (yellow), sample BM20 (yellow ochre). 


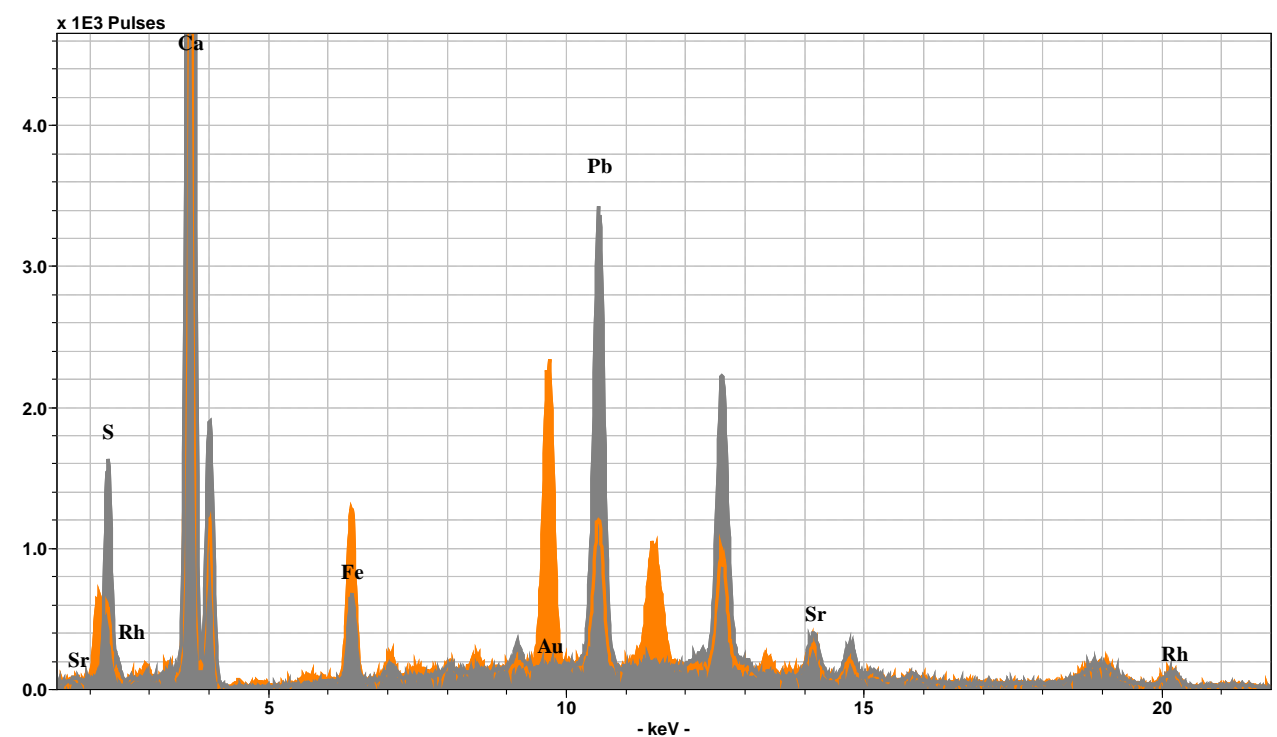

Figure 10. XRF spectra of the ground layer (gray) and the yellow color (yellow), sample HT20 (gold).

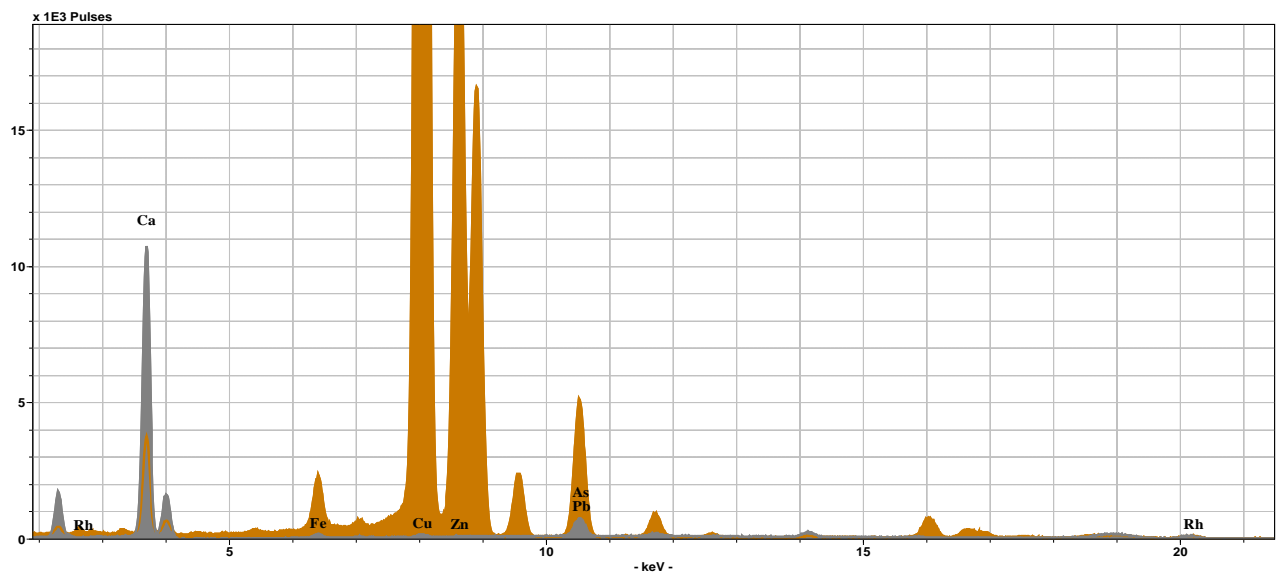

Figure 11. XRF spectra of the ground layer (gray) and the yellow color (yellow), sample KM46 (modern yellow).

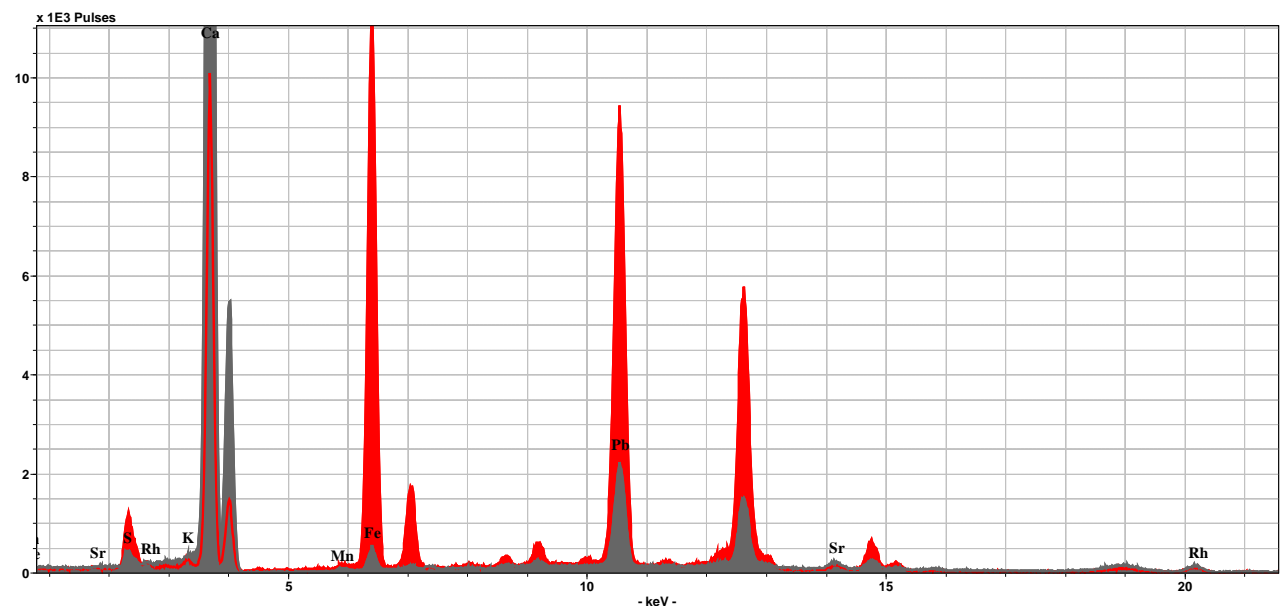

Figure 12. XRF spectra of the ground layer (gray) and the dark red color (red), sample BM21 (red ochre + red lead). 


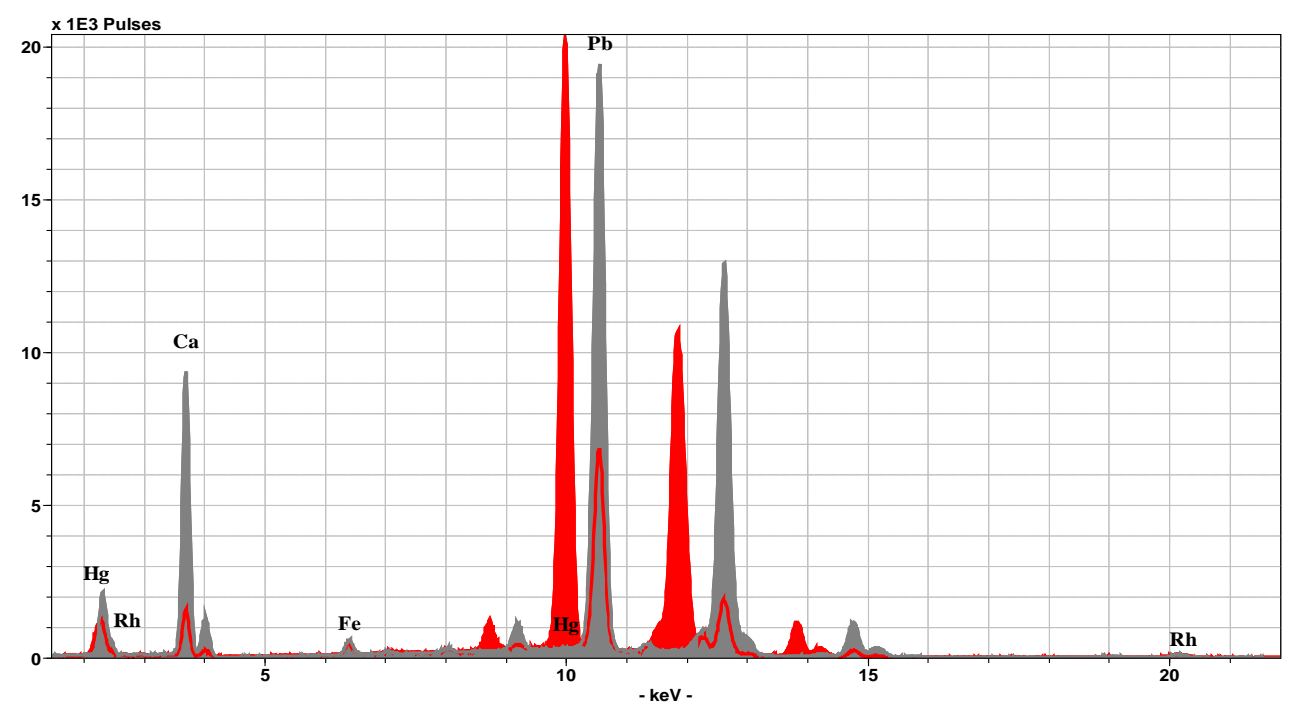

Figure 13. XRF spectra of the ground layer (gray) and the bright red color (red), sample HT41 (cinnabar).

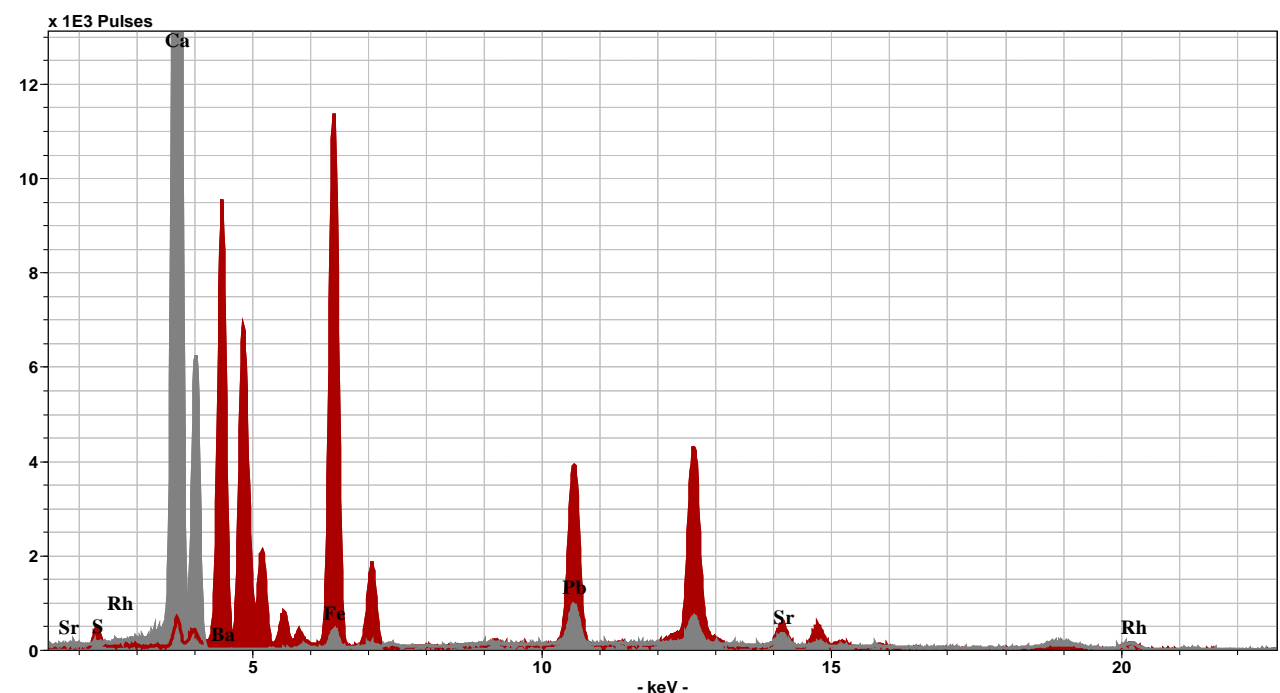

Figure 14. XRF spectra of the ground layer (gray) and the red color (red), sample KM42 (modern red).

Ochre $(\mathrm{Fe})$ and Red lead $(\mathrm{Pb})$, while the presence of $\mathrm{Pb}, \mathrm{Hg}$ and $\mathrm{Fe}$ in the red sample from Bachelor's mosque suggests the application of a mixture of $\mathrm{red} /$ white lead $(\mathrm{Pb})$, cinnabar $(\mathrm{Hg})$ and red ochre $(\mathrm{Fe})$.

We observe a similar calcite layer in the wall painting sample from King Mosque in Figure 17(a) and after that appear two pigment layers with different composition, indicating the presence of over painting. Red lead $(\mathrm{Pb})$ that was first used for the red color is over painted using a modern red containing $\mathrm{Fe}, \mathrm{Ba}$, $\mathrm{Pb}$.

The "line scan" measurement of the sample with yellow color from the ceiling of Helvetia Tekke is presented in Figure 16(a), where are identified three different layers. The first layer is made of gold $(\mathrm{Au})$ and represents the yellow pigment 
Table 2. Results from the samples of Helvetia Tekke.

\begin{tabular}{|c|c|c|c|c|c|}
\hline No & Ground & Element & Colour & Element & Pigment \\
\hline & \multicolumn{5}{|c|}{ Wall painting; Support-wall } \\
\hline HT34 & Lime & $\mathrm{Ca}$ & Yellow & $\mathrm{Fe},(\mathrm{Pb})$ & Yellow ochre \\
\hline HT22, 33a & Lime & $\mathrm{Ca}$ & Red & $\mathrm{Pb}$ & Red lead \\
\hline HT33 & Lime & $\mathrm{Ca}$ & Red & $\mathrm{Pb},(\mathrm{Hg}, \mathrm{Fe})$ & Red lead + (Cinnabar, Red ochre $)$ \\
\hline HT23, 35 & Lime & $\mathrm{Ca}$ & Green-Dark blue & $\mathrm{Cu}, \mathrm{Co}$ & $\mathrm{Cu}$ based green + Smalt \\
\hline \multirow[t]{2}{*}{ HT32 } & Lime & $\mathrm{Ca}$ & Green & $\mathrm{Fe},(\mathrm{Cu}, \mathrm{Pb})$ & Green earth (+Cu based green) \\
\hline & \multicolumn{5}{|c|}{ Decorations of ceiling; Support-wood } \\
\hline HT15, 20a, 26, 27, 28, 30 & Gypsum & $\mathrm{Ca}, \mathrm{S}(\mathrm{Pb})$ & Red & $\mathrm{Pb},(\mathrm{Fe})$ & $\operatorname{Red} \mathrm{Pb}(+$ Red Ochre $)$ \\
\hline HT20, 24, 29 & Gypsum & $\mathrm{Ca}, \mathrm{S}(\mathrm{Pb})$ & Yellow & $\mathrm{Au},(\mathrm{Fe})$ & Gold \\
\hline HT19 & Gypsum & $\mathrm{Ca}, \mathrm{S}(\mathrm{Pb})$ & Dark green & $\mathrm{Fe}, \mathrm{K}$ & Green earth + Carbon (?) \\
\hline HT25 & Gypsum & $\mathrm{Ca}, \mathrm{S}(\mathrm{Pb})$ & Black & $\mathrm{Pb},(\mathrm{Fe})$ & Lead white + Carbon (?) \\
\hline HT31 & Gypsum & $\mathrm{Ca}, \mathrm{S}(\mathrm{Pb})$ & Dark & $\mathrm{Pb},(\mathrm{Fe})$ & Lead white + Carbon (?) \\
\hline \multirow[t]{2}{*}{ HT29 } & Gypsum & $\mathrm{Ca}, \mathrm{S}(\mathrm{Pb})$ & Blue & $\mathrm{Pb}$ & Indigo (?) \\
\hline & \multicolumn{5}{|c|}{ Decoration of other wooden parts; support-wood } \\
\hline HT16 & Gypsum & $\mathrm{Ca}, \mathrm{S}(\mathrm{Pb})$ & Black & $\mathrm{Pb},(\mathrm{Fe})$ & White $\mathrm{Pb}$, Carbon (?) \\
\hline HT17, 39b & Gypsum & $\mathrm{Ca}, \mathrm{S}(\mathrm{Pb})$ & White & $\mathrm{Pb}$ & White lead \\
\hline НТ $38,39,40$ & Gypsum & $\mathrm{Ca}, \mathrm{S}(\mathrm{Pb})$ & Dark red & $\mathrm{Pb},(\mathrm{Hg})$ & Red lead (+Cinnabar) \\
\hline HT41 & Gypsum & $\mathrm{Ca}, \mathrm{S}(\mathrm{Pb})$ & Red & $\mathrm{Hg}$ & Cinnabar + Red lead \\
\hline НT39a & Gypsum & $\mathrm{Ca}, \mathrm{S}(\mathrm{Pb})$ & Dark blue & $\mathrm{Pb},(\mathrm{Cu})$ & Indigo (?) \\
\hline
\end{tabular}

Table 3. Results from the samples of King mosque.

\begin{tabular}{ccccccc}
\hline No & Suport & Grund & Element & Color & Element & Pigment \\
\hline KM37 & Wood & Gypsum & $\mathrm{Ca}, \mathrm{S}+\mathrm{Pb}$ & Red & $\mathrm{Pb},(\mathrm{Ba}, \mathrm{Fe})$ & Red lead \\
KM40 & Wood & Gypsum & $\mathrm{Ca}, \mathrm{S}+\mathrm{Pb}$ & Red & $\mathrm{Fe}(\mathrm{Pb}, \mathrm{As})$ & Red ochre \\
KM38 & Wood & Gypsum & $\mathrm{Ca}, \mathrm{S}+\mathrm{Pb}$ & Dark green & $\mathrm{Fe}, \mathrm{Ba}$ & Green earth + Ba white \\
KM40b & Wood & Gypsum & $\mathrm{Ca}, \mathrm{S}+\mathrm{Pb}$ & Yellow & $\mathrm{Fe}(\mathrm{As})$ & Yellow ochre +orpiment \\
KM44 & Wood & Gypsum & $\mathrm{Ca}, \mathrm{S}+\mathrm{As}$ & Green over yellow & $\mathrm{As}(\mathrm{Fe})$ & Orpiment + Indigo over yellow ochre \\
KM39 & Wood & Gypsum & $\mathrm{Ca}, \mathrm{S}+\mathrm{As}$ & Dark blue & $\mathrm{Fe}(\mathrm{As})$ & Prussian blue on orpiment \\
KM46 & Wall & Gypsum & $\mathrm{Ca}, \mathrm{S}+\mathrm{As}$ & Yellow & $\mathrm{Cu}, \mathrm{Zn}$ & Modern Bronze \\
KM41, 43 & Wall & Calcite & $\mathrm{Ca}$ & Black & & Probably carbon \\
KM42 & Wall & Calcite & $\mathrm{Ca}+(\mathrm{Pb})$ & Red & $\mathrm{Pb}, \mathrm{Fe}, \mathrm{Ba}$ & Red lead + Modern red
\end{tabular}

layer. The second layer, which is identified by the presence of calcium $(\mathrm{Ca})$ and sulfur (S), represents the ground layer made of gypsum (around $0.6 \mathrm{~mm}$ thick). The last white layer, in contact with the wooden support, represents the thin layer of Lead white $(\mathrm{Pb})$ which was applied over the wood. The measurement of a sample with red colour from the ceiling of King Mosque is presented in Figure 16(b). Here the ground layer is made of gypsum, identified by the presence of 
Table 4. Results from the decoration of Bachelor's mosque.

\begin{tabular}{ccccccc}
\hline Nr & Support & Ground & Element & Color & Element & Pigment \\
\hline BM 9*,10* & Wall & Lime & $\mathrm{Ca}$ & Dark Green & $\mathrm{Fe}$ & Green earth \\
BM 23, 24.33 & Wall & Lime & $\mathrm{Ca}$ & Dark Green & $\mathrm{Fe}$ & Green earth \\
BM 11* & Wall & Lime & $\mathrm{Ca}$ & Red & $\mathrm{Pb}, \mathrm{Fe}, \mathrm{Hg}$ & Red lead + Red ochre \\
BM 21 & Wall & Lime & $\mathrm{Ca}$ & Dark red & $\mathrm{Pb}, \mathrm{Fe}$ & Red lead + Red ochre \\
BM 25, 31 & Wall & Lime & $\mathrm{Ca}$ & Light red & $\mathrm{Fe}$ & Red ochre \\
BM 26 & Wall & Lime & $\mathrm{Ca}$ & Bright red & $\mathrm{Hg}$ & Cinnabar \\
BM 12* 20,32 & Wall & Lime & $\mathrm{Ca}$ & Yellow & $\mathrm{Fe}$ & Yellow ochre \\
BM 22 & Wall & Lime & $\mathrm{Ca}$ & Black & - & Carbon (?) \\
BM 29, 30 & Wood & Gypsum & Ca, S & Dark Green & $\mathrm{Fe}$ & Green earth \\
\hline
\end{tabular}

*Samples BM9 - BM12 are taken from the decorations of the outside walls.

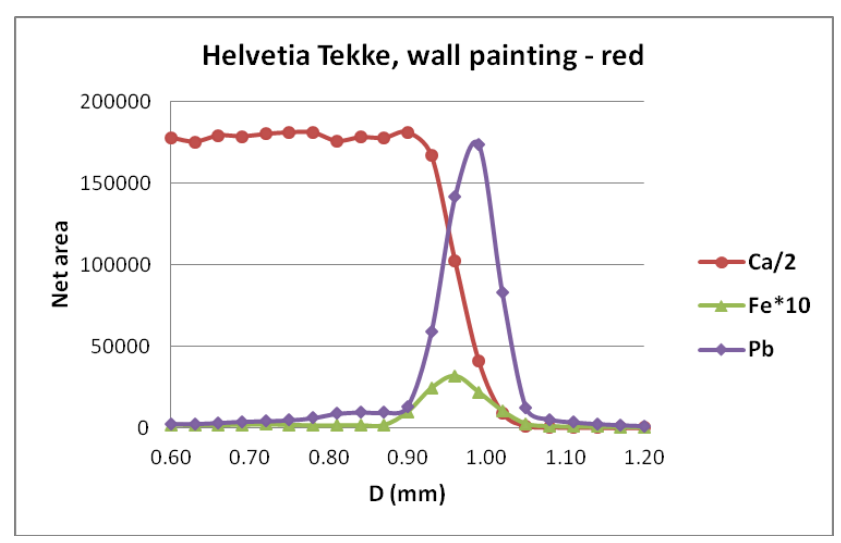

(a)

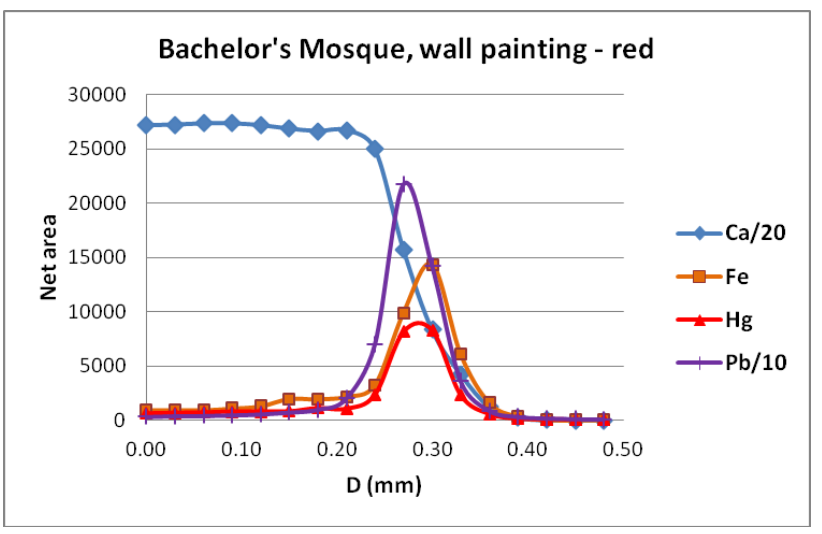

(b)

Figure 15. Variation of the intensity of the main elements through a line of the cross section of wall painting samples' from Helvetia Tekke (a) and Bachelor's mosque (b).

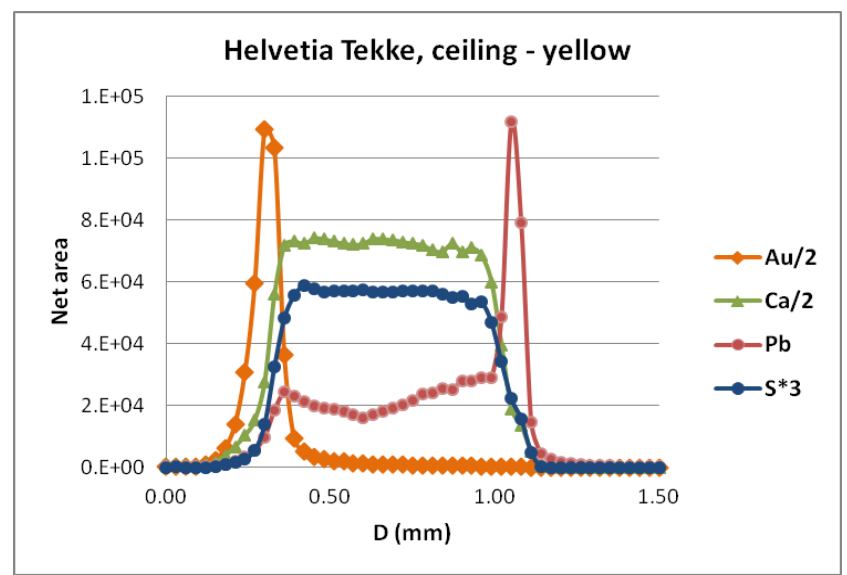

(a)

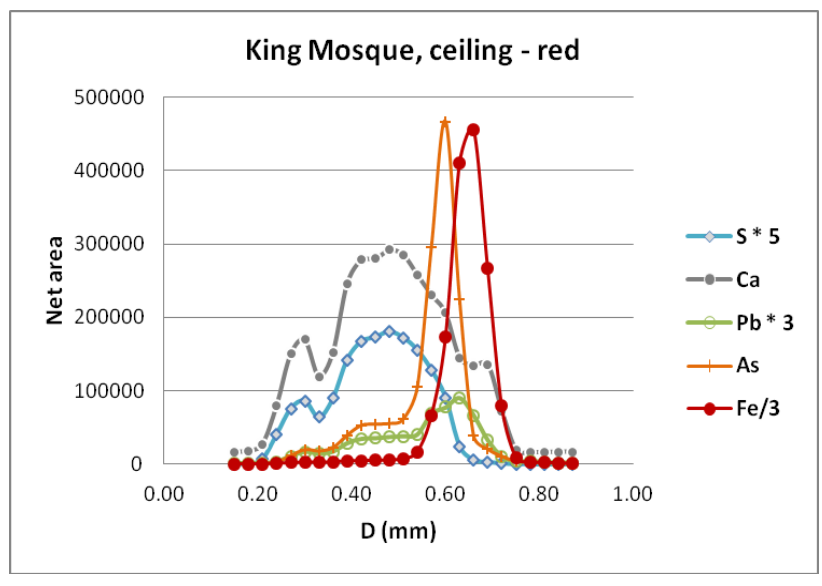

(b)

Figure 16. Variation of the intensity of the main elements through a line of the cross section of samples from paintings on wooden support from Helvetia Tekke (a) and King Mosque (b). 
$\mathrm{Ca}$ and $\mathrm{S}$, applied directly on the wooden support. As regards the pigments, in this case we observe two layers with different composition that appear to be applied one over the other, indicating most probably an over painting. The first layer consisting mostly of As, probably orpiment $\left(\mathrm{As}_{2} \mathrm{~S}_{3}\right)$ used for the yellow or green mixed with indigo [10], was previously applied over the ground layer, while red ochre $(\mathrm{Fe})$ was used for the outer red layer. The small amount of $\mathrm{Pb}$ with maximum intensity just between the two pigment layers' can be an indication of the presence of a thin layer of lead white applied over the first layer.

These results indicate that the wall paintings in the three mosques were prepared using the 'fresco' or "semi-fresco" technique. The paintings on wooden support from the ceilings of Helvetia Tekke and King Mosque were prepared with the technique of tempera, where a thin layer of gypsum is applied on the wooden support and the pigments mixed with a binder were applied on it. Apart from these general similarities the results show some significant differences especially for the painted ceilings of Helvetia Tekke and King Mosque. The first difference is related with the presence of a lead white layer on the wooden support before the gypsum layer at the ceiling of Helvetia Tekke which is missing at the ceiling of King Mosque. This explains the presence of $\mathrm{Pb}$ in the spectra of ground layer of the samples from the ceiling of Helvetia Tekke. The second difference can be considered the existence of wide spread over paintings in the decorations of King Mosque. The over paintings which are clearly observed in Figure 17(b) were also identified by 'line scan' measurements of both paintings from the ceiling and from the wall (Figure 16(b), Figure 17(a)). The existence of over paintings explains the presence of $\mathrm{Pb}$ and/or As in the spectra of the ground in the samples from decorated ceiling of this mosque.

A small number of pigments are used for the beautiful decorations of the ceiling of the praying hall in Helvetia Tekke. Lead white (basic lead carbonate $\left(2 \mathrm{PbCO}_{3} \cdot \mathrm{Pb}(\mathrm{OH})_{2}\right)$ for the white color, red lead $\left(\mathrm{Pb}_{3} \mathrm{O}_{4}\right)$ and red ochre for the red color, green earth for the green color and gold for the yellow color were clearly identified by our measurements. Organic pigments, which cannot be directly identified by XRF, should have been used for the blue and black colors. Based on the absence of inorganic pigments of these colors, the practices of that period and previous studies [11] we can suggest that indigo and black carbon should have been used for the blue and black colors. Mixtures of different pigments were also used for obtaining the desired different hues of the colors.

In lower part of the praying hall either in wall paintings or in paintings on wood, in addition to the above mentioned pigments we have found a few more interesting pigments. The first finding is related with the application of yellow ochre for the yellow color in both wall and wood paintings of this part, instead of gold widely used in the ceiling. Another difference is the use in this part of cinnabar $(\mathrm{HgS})$ as a red pigment, in addition to red lead and red ochre used in the ceiling. In some parts of the wall paintings it looks that cinnabar is applied over the existing red layer and has started to darken due to the deterioration by atmospheric agents [12]. Finally, an interesting green bluish color in the wall 

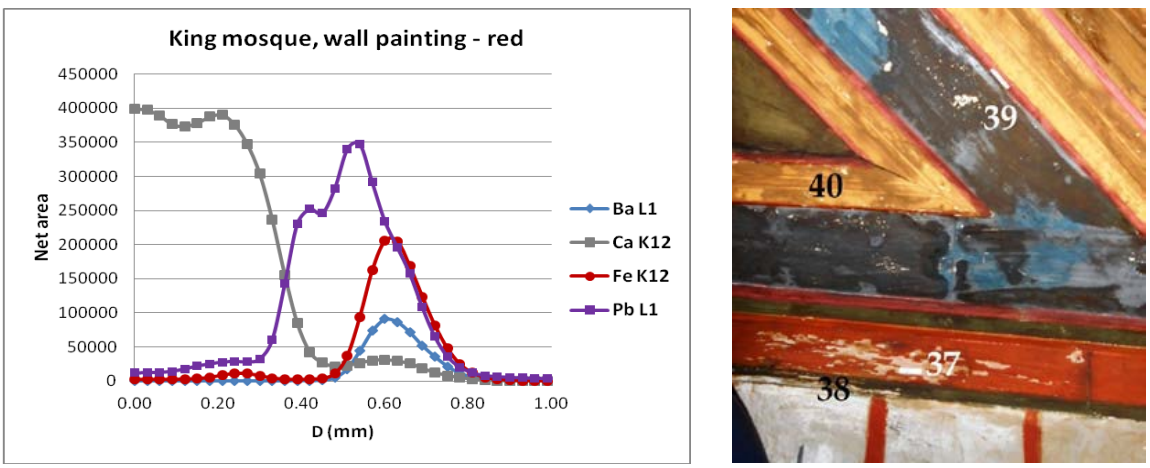

Figure 17. Variation of the intensity of the main elements through a line of the cross section of wall painting sample and photo of a part from the ceiling of King Mosque.

painting appears to have been prepared by a mixture of a $\mathrm{Cu}$ based green pigment (malachite or verdegris) with smalt. The presence of smalt is confirmed by the peaks of $\mathrm{Co}, \mathrm{K}$ and impurities of $\mathrm{Ni}, \mathrm{As}$ and $\mathrm{Bi}$, similar to smalt detected in $17^{\text {th }}$ century icons painted by Onufer Qiprioti and $18^{\text {th }}$ century wall paintings in Voskopoja [13] [14].

A small number of colors (red, green, yellow and black) are used for the beautiful decorations of the walls in Bachelor's Mosque. The measurements of the collected samples indicate the application of green earth, yellow ochre, red ochre, red lead, cinnabar and probably black carbon respectively for the green, yellow, red and black colors. The same types of pigments were used for the decorations of the internal walls of the praying hall and those on the outside walls of the mosque.

The identification of pigments used for the decorations of the ceilings in King Mosque appear to be more complicated due to the presence in the spectra of elements coming from different painted layers. The spectra measured on the samples' ground side classifies them in two groups, one with the presence of $\mathrm{Pb}$ and the other with As. Based on the 'line scan' results that demonstrated the existence of over paintings (Figure 15(b)), the sufficient energy of As Ka and $\mathrm{Pb}$ $\mathrm{La}(10.5 \mathrm{keV})$ to pass through a few tenths of $\mathrm{mm}$ of gypsum, we can suggest that the pigments used in the original decoration were based on these elements. $\mathrm{So}, \mathrm{Pb}$ based pigments, red or white lead, should have been used in the original parts of the decorations with the presence of $\mathrm{Pb}$ in the ground layer spectra, while Orpiment (As) should have been used in the original parts of the decorations with the presence of As in the ground layer spectra. In some of the samples we can clearly observe the underneath layers in red, yellow or green colors related with these pigments.

Pigments used for the upper layers of the decorations can also be divided in two groups, which can probably be related with the re-paintings or restorations at different periods. In some parts we have identified some modern colors such as sample KM37, KM42 with red color or KM38 with green color that both are made of $\mathrm{Fe}, \mathrm{Ba}$ and $\mathrm{Pb}$ or sample KM46 with yellow color that contains $\mathrm{Cu}, \mathrm{Zn}$ (probably bronze particles). In the other parts we have identified pigments 
which resemble more to the original ones. Apart from yellow and red ochre we have identified Orpiment mixed with Indigo for the green color of sample KM44 and Prussian blue $\left[\mathrm{Fe}_{4}\left[\mathrm{Fe}(\mathrm{CN})_{6}\right]_{3} \cdot \mathrm{xH}_{2} \mathrm{O}\right]$ for the dark blue color of sample KM39.

\section{Conclusions}

Micro XRF is successfully used for the identification of the decoration materials and the painting technique used for the decorations of three $18-19^{\text {th }}$ century Islamic religious monuments in Berat. The "line scan" measurements enabled the identification of preparation and pigment layers of the samples. This allowed us to better understand the painting technique used for the different decorations of the monuments, to clearly demonstrate the existence of over paintings as well as contributed to the correct interpretation of pigments' spectra.

In all three monuments, the wall paintings were prepared using the fresco or semi-fresco technique while the tempera technique was used for the paintings on wooden support.

A small number of pigments were identified in the beautiful decorations of the walls in Bachelor's Mosque. They include green earth, yellow ochre, red ochre, red lead, cinnabar and probably black carbon respectively used for the green, yellow, red and black colors.

The artist' palette appears to be richer (number and cost) in the decorations of Helvetia Tekke. It includes lead white, gold, yellow and red ochre, vermilion, red lead, a copper based green and smalt. Organic pigments, probably indigo and carbon black should have been used for the blue and black color.

Red lead, orpiment and Indigo should have used for the original decorations of the ceilings in King Mosque, which are later over painted by other traditional pigments like yellow and red ochre, prussian blue and other modern pigments.

There can be a number of reasons for the observed differences in the painting technique and number and type of pigments used in the decorations of the different monuments and more research from the art historians and restorers is needed for its full explanation. However, the differences of the preparation layers of the ceilings' decorations in Helvetia Tekke and King Mosque suggest that most probably they were decorated by different masters, while the different numbers and type of pigments used either for the ceilings or for the wall paintings could be attributed to the economic contributions of the respective donators.

\section{Conflicts of Interest}

The authors declare no conflicts of interest regarding the publication of this paper.

\section{References}

[1] Riza, E., Meksi, A. and Baçe, A. (1988) Berati, Historia dhe Arkitektura. 8 Nentori, Tiranë.

[2] Meksi, A. (2018) Xhamitë e Shqipërisë. Historia, Arkitektura, shek. XV-XIX. Plejad, 
Tiranë.

[3] Meksi, A. (1979) Restaurimi përfocues në xhaminë e Beqarëve në Berat. Monumentet, 18, 93-104.

[4] Nallbani, H. (1972) Shënime mbi masat restauruese në pikturën e xhamisë së Beqarëve në Berat. Monumentet, 3, 171-175.

[5] Soppi, E. (1990) Mbi disa punime në tavanin e teqesë së Helvetive në Berat. Monumentet, 40, 147-148.

[6] Feller, R. (1985) Artists Pigments: A Handbook of Their History and Characteristics. Vol 1, Cambridge Univ. Press, Cambridge.

[7] Ciliberto, E. and Spoto, G. (2000) Modern Analytical Methods in Art and Archaeology. Chemical Series, Vol. 155, Wiley Sons, New York.

[8] Moens, L., Von Bohlen, A. and Vandenabeele, P. (2000) X-Ray Fluorescence. In: Ciliberto, E. and Spoto, G., Eds., Modern Analytical Methods in Art and Archaeology, Chemical Series, Vol. 155, Wiley Sons, New York, 55-80.

[9] Klockenkamper, R., von Bohlen, A., Moens, L. and Devos, W. (1993) Analytical Characterization of Artists' Pigments Used in Old and Modern Paintings by Total-Reflection X-Ray Fluorescence. Spectrochimica Acta B, 48, 239-246. https://doi.org/10.1016/0584-8547(93)80029-T

[10] Fitzhugh, E.W. (1997) Orpiment and Reaglar. In: Fitzhugh, E.W., Ed., Artists Pigments. A Handbook of Their History and Characteristics, Vol. 3, National Gallery of Art, Washington DC, 47-80.

[11] Civici, N., Demko, O. and Clark, R.J.H. (2005) Identification of Pigments Used on Late 17th Century Albanian Icons by Total Reflection X-Ray Fluorescence and Raman Microscopy. Journal of Cultural Heritage, 6, 157-164.

https://doi.org/10.1016/j.culher.2005.01.002

[12] Cotte, M., Susini, J., Metrich, N., Moscato, A., Gratziu, C., Bertagnini, A. and Pagano, M. (2006) Blackening of Pompeian Cinnabar Paintings: X-Ray Microspectroscopy Analysis. Analytical Chemistry, 78, 7484-7492.

https://doi.org/10.1021/ac0612224

[13] Civici, N. (2006) Non-Destructive Identification of Inorganic Pigments Used in 16-17th Century Albanian Icons by Total Reflection X-Ray Fluorescence Analysis. Journal of Cultural Heritage, 7, 339-343. https://doi.org/10.1016/j.culher.2006.02.010

[14] Pavlidou, E., Civici, N., Anastasiou, L., Çaushi, E., Zorba, T. and Paraskevopoulos, K. (2006) Contributing in the Restoration Process of the 18th Century St. Athanas Church in Moschopolis (Albania). In: Saunders, D., Townsend, J.H. and Woodcock, S., Eds., The Object in Contests: Crossing Conservation Boundaries, International Institute for Conservation of Historic and Artistic Works, London, 328.

https://doi.org/10.1557/PROC-1047-Y03-05 